\title{
Essential oil production of lemongrass (Cymbopogon citratus) under organic compost containing sewage sludge
}

\author{
Júlia V. d’Avila ${ }^{1}$, Ana P. Martinazzo ${ }^{1}$, Fabiana S. dos Santos ${ }^{1}$, Carlos E. de S. Teodoro ${ }^{1} \&$ Adriano Portz $^{1}$ \\ ${ }^{1}$ Universidade Federal Fluminense/Departamento de Engenharia de Agronegócios. Volta Redonda, RJ. E-mail: juliavaledavila@gmail.com; \\ anapaulamartinazzo@id.uff.br (Corresponding author); fabianasoares@id.uff.br; eduardo@metal.eeimvr.uff.br; aportz@id.uff.br
}

\section{Key words: \\ solid waste \\ medicinal plant \\ composting \\ mineral nutrition}

\begin{abstract}
A B S T R A C T
One of the main urban polluting agents are the sewers, which even with proper treatment end up generating a polluting waste, the sewage sludge. One of the options for the disposal of this sludge is the use in agriculture, due to its high content of organic matter and nutrients. This study aimed to use urban sewage sludge for lemongrass cultivation and essential oil production. The plants were grown in soil containing different organic compost doses $\left(0,5,10,20,40\right.$ and $\left.60 \mathrm{t} \mathrm{ha}^{-1}\right)$, formed from the sewage sludge composting process and waste of urban vegetation pruning. At harvest, plants were analyzed for the concentration of nutrients, chlorophyll content, number of tillers, biomass production, essential oil content and the microbiological quality of the leaves. The results showed that the addition of the compost increased the levels of nutrients in the plants, mainly nitrogen, positively influencing the production of tillers, biomass, chlorophyll contents, yield and essential oil content.
\end{abstract}

\section{Palavras-chave:}

resíduos sólidos planta medicinal compostagem nutrição mineral

\section{Produção de óleo essencial de capim-limão (Cymbopogon citratus) sob composto orgânico contendo lodo de esgoto}

\section{R E S U M O}

Um dos principais agentes poluidores urbanos são os esgotos que, mesmo com o devido tratamento, acabam por gerar um resíduo poluente, o lodo de esgoto. Uma das opções para destinação deste lodo é sua utilização na agricultura em virtude do alto teor de matéria orgânica e nutrientes. Objetivou-se, com este trabalho, o aproveitamento de lodo de esgoto urbano para o cultivo de capim-limão, além da produção de óleo essencial. As plantas foram cultivadas em solo contendo doses de composto orgânico $(0,5,10,20,40$ e $\left.60 \mathrm{t} \mathrm{ha}^{-1}\right)$, formado a partir do processo de compostagem de lodo de esgoto e resíduos de poda de vegetação urbana. Na colheita foram analisadas as concentrações de nutrientes nas plantas, os teores de clorofila, número de perfilhos, produção de biomassa, óleo essencial e a qualidade microbiológica das folhas. Os resultados demonstraram que a adição do composto aumentou os teores de nutrientes nas plantas sobretudo o nitrogênio, influenciando positivamente na produção de perfilhos, biomassa, teores de clorofila, rendimento e teor do óleo essencial. 


\section{INTRODUCTION}

One option for the safe destination of sewage sludge is its application in the soil for agricultural cultivation, due to its high content of organic matter and nutrients to plants. Many studies have demonstrated increases in the production of dry matter and/or grains by species of agronomic interest cultivated in soils treated with sewage sludge (Lobo et al., 2012; Albuquerque et al., 2015; Freitas et al., 2015); however, the polluting effect of sewage sludge is related to the levels of microorganisms and heavy metals that it may contain. The presence of microorganisms is undesirable, because of the risks to human and animal health (Backes et al., 2009; Fialho et al., 2010). The heavy metals, on the other hand, constitute a barrier for the use of sludge in productive processes, besides the possible contamination of the environment (Silva et al., 2001). Therefore, it becomes necessary to develop safe and feasible alternatives for the use of this waste (Bettiol \& Camargo, 2006).

The CONAMA Resolution $n^{\circ} 375 / 2006$ (Brasil, 2006) is the instrument that defines the criteria and procedures for the agricultural use of sewage sludge in Brazil. This resolution establishes that, for the use of sludge to adequately meet the quality criteria, its agronomic potential must be taken into account, along with the quantification of potentially toxic inorganic and organic substances, such as the presence of pathogenic agents.

The species Cymbopogom citratus is used and applied in the industries of pharmaceuticals, food, cosmetics and perfumes, due to its essential oil (Bakkali et al., 2008). Given the above, this study aimed to evaluate the production of C. citratus cultivated in substrate formed by the mixture of soil and increasing doses of organic compost obtained from the combination of sewage sludge and residues from the conservation pruning of plants of streets and urban squares.

\section{Material ANd Methods}

The sewage sludge was collected in a sewage treatment station in Volta Redonda, RJ, Brazil, and subjected to chemical and microbiological analyses, considering all the parameters determined by the Resolution $\mathrm{n}^{\circ} 375 / 2006$ (Brasil, 2006). According to the analysis, the levels of organic and inorganic pollutants were within the limits established by the legislation. As to the biological contaminants, there were amounts of thermotolerant coliforms (1,090,000 MPN g-1 of TS) and Salmonella, (59 P/A in $10 \mathrm{~g}$ of DM) above the acceptable levels. Thus, the composting process was performed in order to achieve the reduction of these pathogens.

The produced organic compost came from the composting of a mixture of sewage sludge with urban pruning residues, from the conservation of streets and urban areas, composed of wood, tree leaves and grass, at the proportion of 19:1 (sewage sludge: urban pruning residue), so that the $\mathrm{C} / \mathrm{N}$ ratio was around 30 .

After composting, the organic compost was subjected to microbiological analyses, which indicated the reduction of the levels of thermotolerant coliforms, to values lower than the maximum limits allowed by the legislation, and absence of Salmonella.

The experiment was carried out in a greenhouse, in which the mean temperature during the cultivation was $30.3^{\circ} \mathrm{C}$. The soil used was collected at the $0-20 \mathrm{~cm}$ depth and classified as moderate A Tb typic eutrophic Haplic Planosol, with sandy texture (EMBRAPA, 2006).

Table 1 shows the main chemical characteristics of the soil used in the experiment and the concentration of macronutrients, $\mathrm{pH}$ and organic carbon in the organic compost. The compost has substantial amounts of calcium $(\mathrm{Ca})$, magnesium $(\mathrm{Mg})$ and nitrogen $(\mathrm{N})$, nutrients that are essential for good development of the shoots, an organ of agronomic and commercial interest of this species.

The tests were conducted in 5 - $\mathrm{L}$ plastic pots, for the evaluation of 5 doses of the organic compost $(5,10,20,40$ and 60 $\mathrm{t} \mathrm{ha}^{-1}$ - plus a control, $\left.0 \mathrm{tha}^{-1}\right)$. The doses were determined based on the recommendations of organic and mineral $\mathrm{N}$ fertilizations for the crop (Bhan et al., 1999) and according to the amount of $\mathrm{N}$ found in the chemical analysis of the compost. Since the proportion of $\mathrm{N}$ in the organic compost that is recovered by the crop immediately after fertilization depends on various factors, such as characteristics of the fertilizer, climate, soil and crop cycle, a mean $\mathrm{N}$ recovery of around 20\% (Freire et al., 2013) was estimated under the experimental conditions, which was equivalent to $28,56,96,192$ and $336 \mathrm{~kg}$ of $\mathrm{N} \mathrm{ha}^{-1}$. Thus, the compost was mixed with the soil and the samples were arranged in a completely randomized design with 3 replicates, totaling 18 experimental units. $60 \mathrm{~kg} \mathrm{ha}^{-1}$ of potassium chloride and $30 \mathrm{~kg} \mathrm{ha}^{-1}$ single superphosphate were applied, based on the recommendations for the crop (Bhan et al., 1999).

Plants were cultivated for six months, during the spring and summer, and irrigations were performed always when necessary, in order to maintain soil moisture close to field capacity. At harvest, chlorophyll a, b, total chlorophyll and carotenoids were extracted and quantified according to Hiscox \& Israelstam (1979). Fresh and dry biomass, number of tillers and percentages of nitrogen $(\mathrm{N})$, phosphorus $(\mathrm{P})$, potassium $(\mathrm{K})$, calcium $(\mathrm{Ca})$ and magnesium $(\mathrm{Mg})$ in the leaves were determined according to Tedesco et al. (1995).

The water content in the leaves was obtained through the gravimetric method (ASAE, 2000). The essential oil was extracted through hydrodistillation with a Clevenger apparatus, for $90 \mathrm{~min}$ for samples of $90 \mathrm{~g}$ of fresh leaves (Martinazzo et al., 2013). The compounds citral and myrcene were identified

Table 1. Chemical characteristics of the Haplic Planosol and the organic compost used in the cultivation

\begin{tabular}{|c|c|c|c|c|c|c|c|c|c|c|c|c|c|c|c|}
\hline \multicolumn{9}{|c|}{ Haplic Planosol } & \multicolumn{7}{|c|}{ Organic compost } \\
\hline \multirow{2}{*}{$\mathrm{pH}_{(\mathrm{H} 20)}$} & $\mathbf{P}$ & $\mathbf{K}^{+}$ & $\mathrm{Ca}^{2+}$ & $\mathrm{Mg}^{2+}$ & $\mathrm{Al}^{3+}$ & $\mathrm{Na}^{+}$ & $\mathbf{N}_{\text {total }}$ & TOC & \multirow{2}{*}{$\mathrm{pH}_{(\mathrm{H} 20)}$} & $P$ & $K$ & $\mathrm{Ca}$ & $\mathrm{Mg}$ & $\mathrm{N}$ & $O C$ \\
\hline & $\mathrm{mg} \mathrm{dm}^{-3}$ & & & $\mathrm{~mol}_{\mathrm{c}} \mathrm{dn}$ & & & & & & \multicolumn{6}{|c|}{$\mathrm{g} \mathrm{kg}^{-1}$} \\
\hline 6.09 & 3.61 & 0.03 & 2.30 & 1.10 & 0.05 & 0.00 & 2 & 9.9 & 5.49 & 9.2 & 2.2 & 12.9 & 11.9 & 28.0 & 149.1 \\
\hline
\end{tabular}

TOC - Total organic carbon, OC - Organic carbon 
through gas chromatography-mass spectrometry (Shimadzu GCMS QP2010 plus), using a DB-5 chromatographic column. The temperature was equal to $220^{\circ} \mathrm{C}$ in the injector and 240 ${ }^{\circ} \mathrm{C}$ in the detector, with run time of $91 \mathrm{~min}$. The quantitative analysis was performed through the method of normalization of integration of the area of the peaks, according to Zhang et al. (2006).

Salmonella sp. and total coliforms were analyzed through fast methods, using 1-2 Test and Simplate kits (BioControl ${ }^{\circledR}$ ), respectively, which are approved by the AOAC (2005). The samples were prepared according to the manuals.

The effects of quantitative factors were evaluated through regression analysis. The criterion for the selection of the most adequate regression model considered the analysis of variance, coefficient of determination and the significance of regression parameters.

\section{Results AND Discussion}

The contents of chlorophyll a and b, carotenoids and total chlorophyll in the cultivated plants can be seen in Figure 1, where the data relate the amounts of pigments with the different doses of sewage sludge applied.

For all studied pigments, the relationship was positive and significant with the applied doses of the organic compost, which demonstrates that, as the organic compost doses increased, there was an increment in the production of pigments by the plant, probably due to the larger amount of $\mathrm{N}$ present in the compost. Similar results were observed by Trigueiro \& Guerrini (2003) in a study on the use of biosolid containing sewage sludge as a substrate for the production of eucalyptus seedlings, in which the leaf content of chlorophyll was higher with the biosolid.

The number of tillers and the production of fresh and dry biomass $\left(\right.$ g plant $^{-1}$ ) are shown in Figure 2 .

There was a relationship between the production of tillers and the applied doses of organic compost, observed through the increasing linear model. Regarding dry and fresh biomass, it can be noted that the behavior of the model was increasing and quadratic; even considering that the compost positively influenced biomass, there was a point corresponding to an approximate addition of $40 \mathrm{t} \mathrm{ha}^{-1}$ of compost at which its increase no longer followed the addition of the applied dose proportionally. This demonstrates that there was a factor that limited the constant of this development, which may be related to the volume of the pots used in the experiment, thus being subject to the effects of the confinement of the root system or the competition between the leaves, for water, light and space, resulting in the deceleration of biomass production (Prins et al., 2008).

Costa et al. (2008), working with mineral and organic fertilizations, observed that the latter promoted better results in the number of tillers, shoot dry biomass accumulation and essential oil yield of lemongrass plants.

The mean percentage of essential oil yield of lemongrass leaves, in the treatments, is represented in Figure 3 and the results were obtained in relation to the water contents in the leaves, after harvest, which was equal to 2.44 d.b. (dry basis).
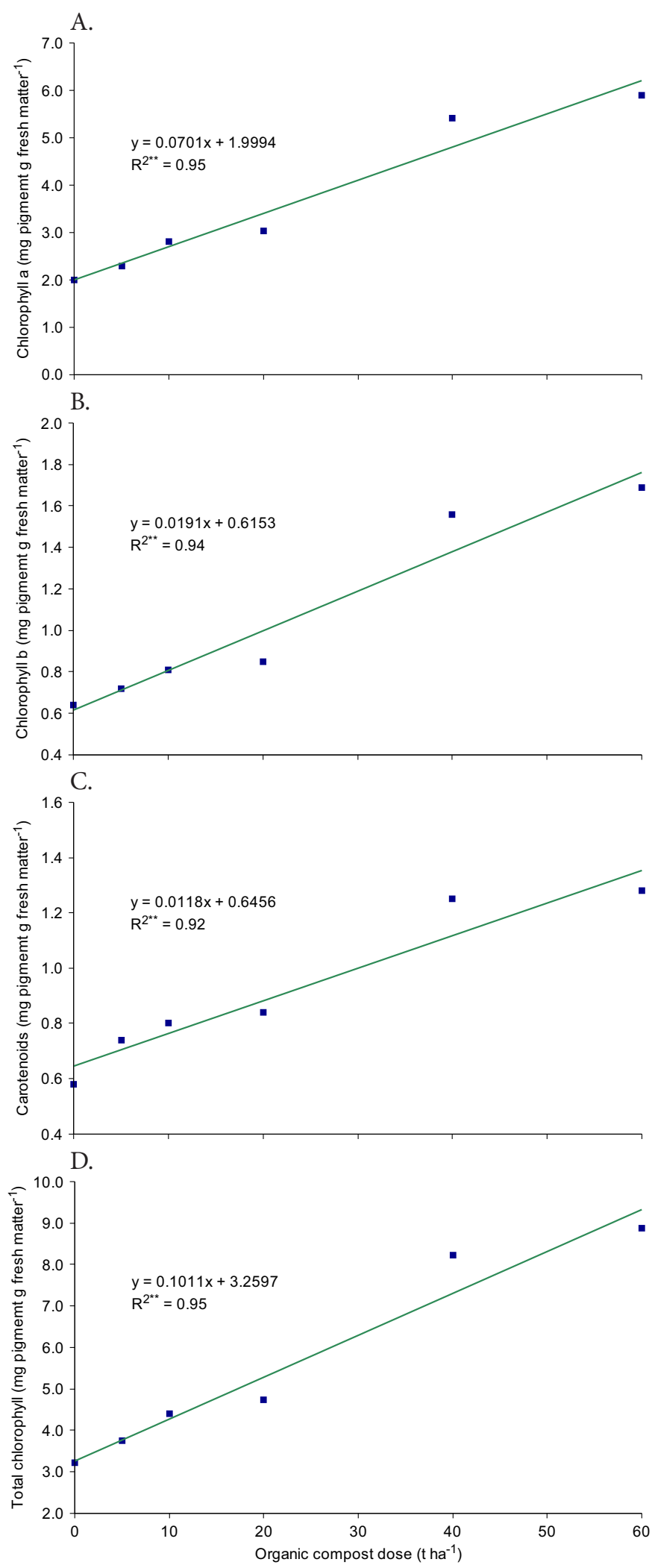

** Significant at 0.01 probability level

Figure 1. Means of chlorophyll a (A), chlorophyll b (B), carotenoids (C) and total chlorophyll (D) in lemongrass cultivated with doses of organic compost containing sewage sludge

Figure 3 demonstrates that there was influence of the organic compost on essential oil yield, 1.07 g plant $^{-1}$ for the control and 1.40 g plant $^{-1}$ for the highest applied dose $\left(60 \mathrm{t} \mathrm{ha}^{-1}\right)$, due to the increase in biomass. Costa et al. (2008) evaluated the effect of chemical and organic fertilizations on the production 

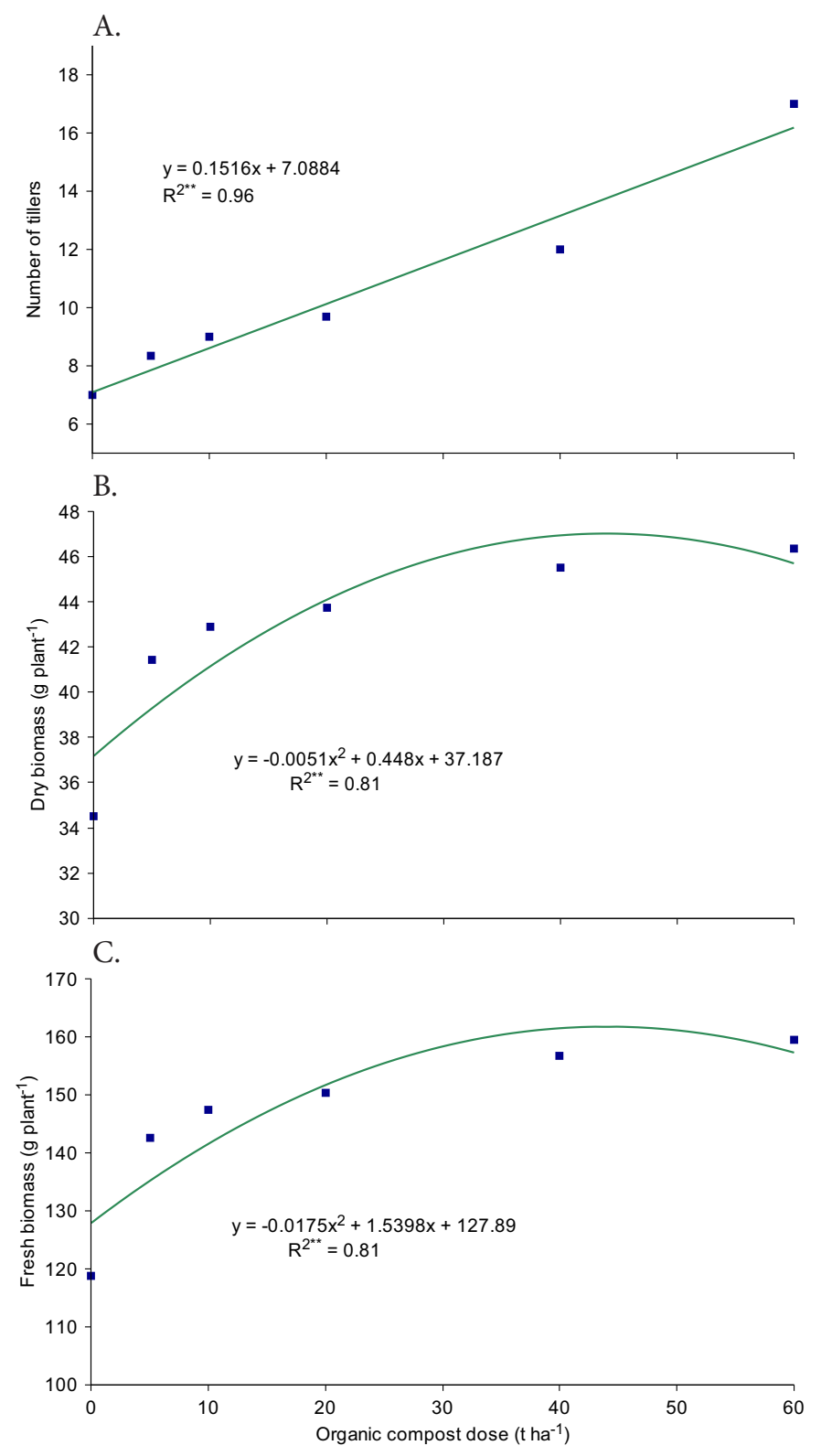

${ }^{* * \text { Significant at } 0.01 \text { probability level }}$

Figure 2. Means of number of tillers (A), dry biomass (B) and fresh biomass $(C)$ of lemongrass cultivated with doses of organic compost containing sewage sludge

of biomass and essential oil in lemongrass and obtained yield of $0.89 \mathrm{~g} \mathrm{plant}^{-1}$ of essential oil with the application of $125 \mathrm{~g}$ pot $^{-1}$ of the compost formed by decomposition of vegetal and animal organic matter, which contained $5 \mathrm{~g} \mathrm{~kg}^{-1}$ of $\mathrm{N}$. The compost used in the present study contained $28.0 \mathrm{~g} \mathrm{~kg}^{-1}$ of $\mathrm{N}$, which explains the difference between the obtained amounts, demonstrating how $\mathrm{N}$ positively influences oil yield. Likewise, Hendawy \& Khalid (2011) studied the effect of organic and chemical fertilizers on the essential oil of chamomile and concluded that the applied organic compost promoted a positive effect on the content of essential oil, especially due to the nutrients $\mathrm{N}, \mathrm{P}$ and $\mathrm{K}$.

The mean content of essential oil, as a function of the applied dose, is presented in Figure 3B. According to the increasing and quadratic model obtained in the regression, the organic compost positively influenced the content of essential oil. According to the model, the ideal maximum dose
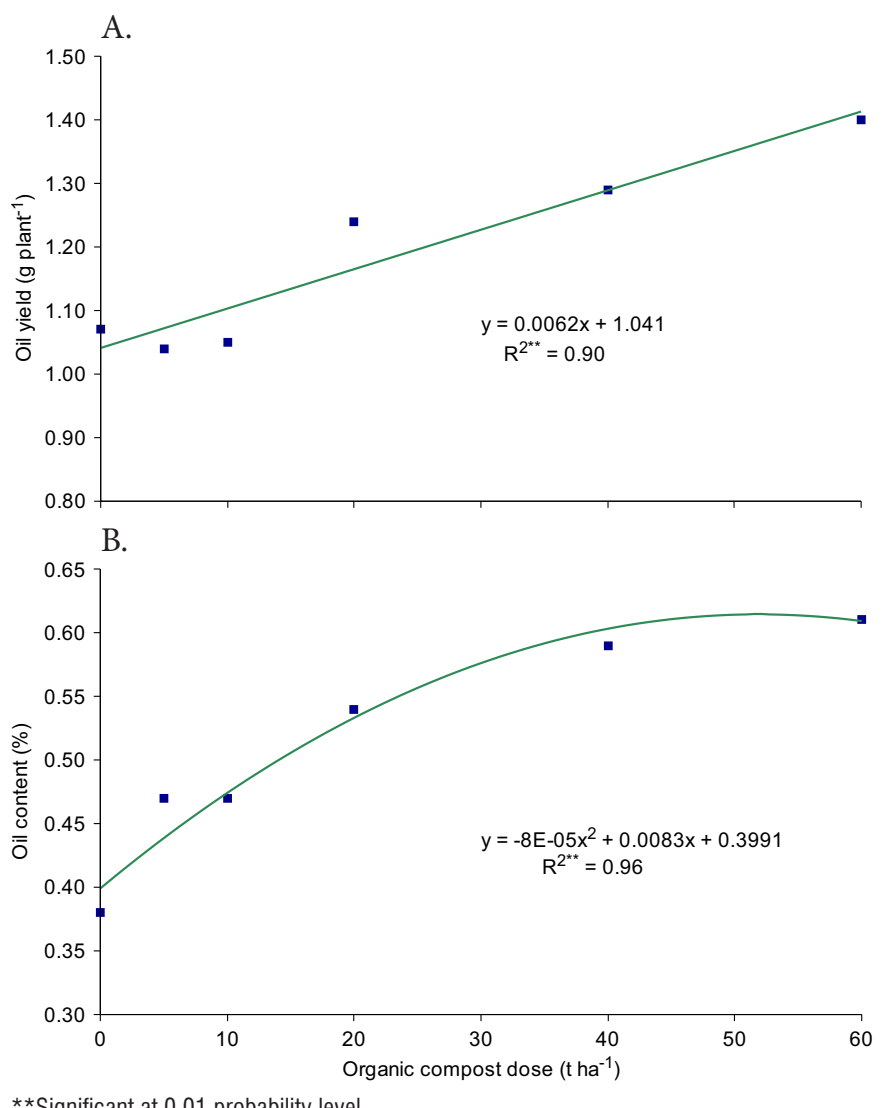

**Significant at 0.01 probability level

Figure 3. Means of oil yield (A) and oil content (B) for lemongrass cultivated with different doses of organic compost containing sewage sludge

of the organic compost was determined for the production of essential oil under the evaluated experimental conditions, with the estimation that the dose of $52 \mathrm{t} \mathrm{ha}^{-1}$ would produce $0.61 \%$ of lemongrass essential oil, a dose at which the compost would contain $1.45 \mathrm{tha}^{-1}$ of $\mathrm{N}$. For the production of the vegetal drug, the Farmacopeia Brasileira V (2003) recommends a minimum content of $0.5 \%$ of essential oil in dry leaves.

Studies on lemongrass cultivation under various conditions have demonstrated the variation in its essential oil yield: Figueiredo et al. (2006) obtained oil content from 0.2 to $0.5 \%$; Costa et al. (2008) reported results around 1.6\%, while Santos et al. (2009) determined values ranging from 0.49 to $1.15 \%$ in cultivation in beds. For Morais (2009), these differences are explained by the fact that the production and chemical composition of the essential oils are determined by genetic factors of the plant, besides other factors that may lead to significant alterations in its production, such as interactions between plants, with microorganisms, insects, age and development stage of the species, abiotic factors such as luminosity, temperature, rainfall, nutrition and harvest period and time.

For the component citral (neral+geranial), the main component of the essential oil, the regression test was not significant, indicating that the addition of the compost to the soil did not influence its production. The mean value obtained for this component was $75.59 \%$, with coefficient of variation of $3.13 \%$ between the treatments. For the production of the vegetal drug, the Farmacopeia Brasileira V (2003) recommends a minimum value of $60 \%$ of citral in the essential oil. In 


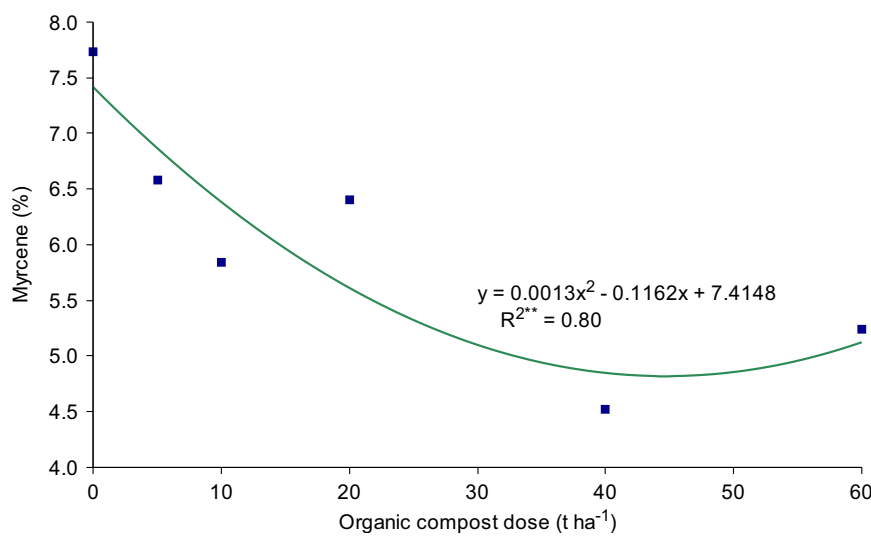

**Significant at 0.01 probability level

Figure 4. Means of yield of the component myrcene of essential oil of lemongrass cultivated with different doses of organic compost containing sewage sludge

Brazilian plantations, its content ranges from 75 to $86 \%$, which is satisfactory in the international market (Guimarães et al., 2008).

Figure 4 shows the behavior between the variables compost doses and myrcene yield, which was significant according to the analysis of variance.

It is observed that the relationship between myrcene and compost doses was decreasing, demonstrating that the compost negatively influences this component. The minimum value for the amount of myrcene determined by the model was estimated as $4.82 \%$ at the dose of $45 \mathrm{t} \mathrm{ha}^{-1}$. The contents of myrcene reported in plantations are variable for the species, from 2 to 25.3\% (Negrelle \& Gomes, 2007). The Farmacopeia Brasileira V (2003) does not establish the minimum value of this component.

As to the microbiological quality of lemongrass leaves, in all treatments the plants are in agreement with the determination of the RDC n ${ }^{\circ} 12 / 2001$ of ANVISA (Brasil, 2001), which is absence of Salmonella sp. and a maximum of $10^{2} \mathrm{CFU} \mathrm{g}^{-1}$ for thermotolerant coliforms, which are within the specifications of total coliforms in the legislation.

The percentages of total $\mathrm{N}, \mathrm{P}, \mathrm{Ca}$ and $\mathrm{Mg}$ obtained in lemongrass leaves, in relation to the applied doses, are presented in Figure 5.

For the analyzed nutrients, the behavior of the model was increasing, demonstrating the effect of the compost containing sewage sludge on the availability and absorption of nutrients by the plants. For K, there was a linear behavior, while for the others the model showed a quadratic behavior. The nutrient $\mathrm{P}$ was not shown in Figure 5 because the adjustment was not significant in the regression test, i.e., the addition of the compost did not influence its absorption by the plant.

The increase in the amount of nutrients, especially $\mathrm{N}$, $\mathrm{Ca}$ and $\mathrm{Mg}$, in lemongrass fertilized with organic compost containing sludge, is related to their contents added through the compost. Lopes et al. (2005), studying the production of lettuce with sewage sludge doses, observed an increment of $\mathrm{N}$, $\mathrm{Ca}$ and $\mathrm{Mg}$ in the plant, as the applied dose of sewage sludge increased, which is related to the various characteristics found in the present study, such as biomass production, tillers and chlorophyll.
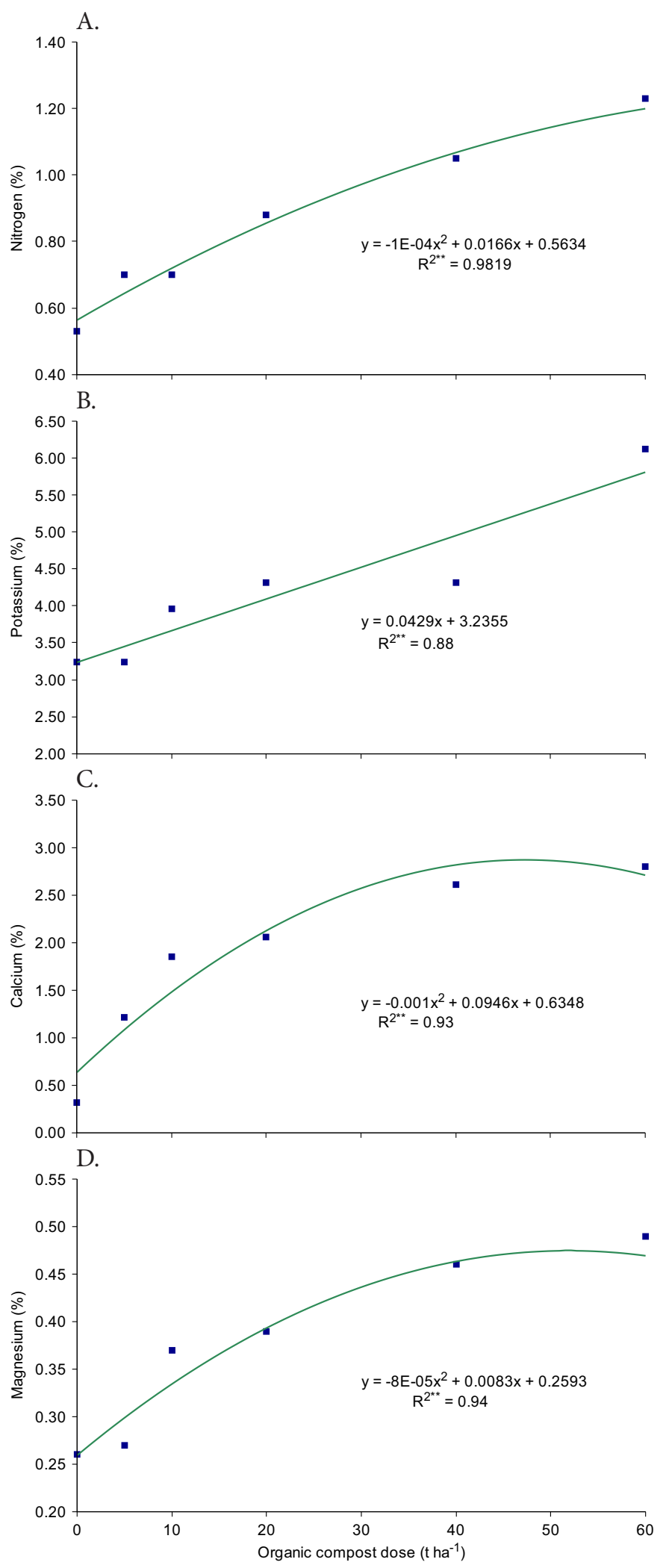

${ }^{* \star}$ Significant at 0.01 probability level

Figure 5. Values of nitrogen (A), potassium (B), calcium (C) and magnesium (D) in leaves of lemongrass cultivated with organic compost containing sewage sludge

\section{Conclusions}

1. The application of organic compost containing sewage sludge significantly influenced the increase in the production of tillers and pigments in lemongrass plants. 
2. For essential oil yield and content, the addition of compost containing sewage sludge had positive influence, but it had no direct influence on citral and showed negative influence on myrcene.

\section{Literature Cited}

Albuquerque, H. C.; Junio, G. R. Z.; Sampaio, R. A.; Fernandes, L. C.; Zonta, E.; Barbosa, C. F. Yield and nutrition of sunflower fertilized with sewage sludge. Revista Brasileira de Engenharia Agrícola e Ambiental, v.19, p.553-559, 2015. http://dx.doi.org/10.1590/18071929/agriambi.v19n6p553-559

AOAC - Association of Official Analytical Chemistry. Official methods of analysis, 18.ed., Gaithersburg: AOAC, 2005. 326p.

ASAE - American Society of Agricultural Engineers. Moisture measurement in forages. In: Standards engineering practices data. St. Joseph: ASAE, 2000. p.565-572.

Backes, C.; Bull, L. T.; Godoy, L. J. G.; Boas, R. L. V. Uso de lodo de esgoto na produção de tapetes de grama esmeralda. Ciência Rural, v.39, p.1045-1050, 2009. http://dx.doi.org/10.1590/S010384782009000400014

Bakkali, F.; Averbeck, S.; Averberck, D.; Idaomar, M. Biological effects of essential oils. Food and Chemical Toxicology, v.46, p.446-475, 2008. http://dx.doi.org/10.1016/j.fct.2007.09.106

Bettiol, W.; Camargo, O. A. Lodo de esgoto: Impactos ambientais na agricultura. Jaguariúna: Embrapa Meio Ambiente, 2006. 349p.

Bhan, M. K.; Kanti, R.; Kak, S.; Pal, S.; Rekha, K. Response of new improved strain RL-931 of Cymbopogon to nitrogen fertilization. Journal of Medicinal and Aromatic Plant Sciences, v.21, p.10271029, 1999.

Brasil. Agência Nacional de Vigilância Sanitária. Resolução RDC nº 12 de 02 de janeiro de 2001. Diário Oficial da União; 10 de janeiro de 2001, Brasília.

Brasil. Conselho Nacional do Meio Ambiente. Resolução nº 375 de 29 de agosto de 2006. Diário Oficial da União; 30 de agosto de 2006, Brasília.

Costa, L. C. B.; Rosal, L. F.; Pinto, J. E. B. P.; Bertolucci, S. K. V. Efeito da adubação química e orgânica na produção de biomassa e óleo essencial em capim-limão. Revista Brasileira de Plantas Medicinais, v.10, p.16-20, 2008.

EMBRAPA - Empresa Brasileira de Pesquisa Agropecuária. Sistema brasileiro de classificação de solos. 2.ed. Rio de Janeiro: Embrapa STI, 2006. 306p.

Farmacopéia Brasileira V. 4.ed. Parte V, São Paulo: Atheneu, 2003. $364 p$.

Fialho, L. L.; Silva, W. T.; Milori, D. M.; Simões, M.; Martin Neto, L. Characterization of organic matter from composting of different residues by physicochemical and spectroscopic methods. Bioresource Technology, v.101, p.1927-1934, 2010. http://dx.doi. org/10.1016/j.biortech.2009.10.039

Figueiredo, R. O.; Delachiave, M. E. A.; Ming, L. C. Reguladores vegetais na produção de biomassa e teor de óleos essenciais em Cymbopogon citratus em diferentes épocas do ano. Revista Brasileira de Plantas Medicinais, v.8, p.31-35, 2006.

Freire, L. R.; Balieiro, F.; Zonta, E.; Anjos, L. H.; Pereira, M. Manual de calagem e adubação do Estado do Rio de Janeiro. Seropédica: Universidade Federal Rural do Rio de Janeiro, 2013. 430p.
Freitas, A. R.; Lopes, J. C.; Alexandre, R. S.; Venancio, L .P.; Zanotti, R. F. Emergência e crescimento de mudas de maracujá doce em função de lodo de esgoto e luz. Comunicata Scientiae, v.6, p.234-240, 2015.

Guimarães, L. G. L.; Cardoso, M. G.; Zacaroni, L. M.; Lima, R. K.; Pimentel, F. A. Influência da luz e da temperatura sobre a oxidação do óleo essencial de capim-limão (Cymbopogon citratus). Química Nova, v.31, p.1476-1480, 2008. http://dx.doi.org/10.1590/S010040422008000600037

Hiscox, J. D.; Israelstam, G. F. A method for the extraction of chlorophyll from leaf tissue without maceration. Canadian Journal of Botany, v.57, p.1332-1334, 1979. http://dx.doi.org/10.1139/ b79-163

Hendawy, S. F.; Khalid, K. A. Effect of chemical and organic fertilizers on yield and essential oil of chamomile flower heads. Medicinal Aromatic Plant Science and Biotechnology, v.5, p.43-48, 2011.

Lobo, T. F.; Grassi Filho, H.; Büll, L. T. Efeito do nitrogênio e do lodo de esgoto nos fatores produtivos do feijoeiro. Revista Ceres, v.59, p.118-124, 2012. http://dx.doi.org/10.1590/S0034737X2012000100017

Lopes, J. C.; Ribeiro, L. G.; Araújo, M. G.; Beraldo, M. R. B. S. Produção de alface com doses de lodo de esgoto. Horticultura Brasileira, v.23, p.143-147, 2005. http://dx.doi.org/10.1590/S010205362005000100030

Martinazzo, A. P.; Melo, E.; Demuner, A.; Berbert, P. Avaliação do óleo essencial de folhas de C. citratus após o processo de secagem. Blacpma, v.12, p.523-536, 2013.

Morais, L. A. S. Influência dos fatores abióticos na composição química dos óleos essenciais. Horticultura Brasileira, v.27, p.S4050-S4063, 2009.

Negrelle, R. R. B.; Gomes, E. C. Cymbopogon citratus: Chemical composition and biological activities. Revista Brasileira de Plantas Medicinais, v.9, p.80-92, 2007.

Prins, C. L.; Freitas, S. P.; Campostrini, E.; Gravina, G. Efeitos de confinamento do sistema radicular sobre capim-limão. Revista Ciência Agronômica, v.39, p.416-421, 2008.

Santos, A.; Paduan, R. H.; Gazin, Z.; Jacomassi, E. Determinação do rendimento e atividade antimicrobiana do óleo essencial de $C$. citratus em função de sazonalidade e consorciamento. Brazilian Journal of Pharmacognosy, v.19, p.436-441, 2009. http://dx.doi. org/10.1590/s0102-695x2009000300017

Silva, F. C.; Boaretto, A. E.; Berton, R. S.; Zotelli, H. L.; Pexe, C. A.; Bernardes, E. Efeito de lodo de esgoto na fertilidade de um argissolo vermelho-amarelo cultivado com cana-de-açúcar. Pesquisa Agropecuária Brasileira, v.36, p.831-840, 2001. http:// dx.doi.org/10.1590/S0100-204X2001000500014

Tedesco, M. J.; Gianello, C.; Bissani, C. A.; Bohnen, H.; Volkweiss, S. J. Análise de solo, plantas e outros materiais. Porto Alegre: UFRS, 1995. 174p.

Trigueiro, R. M.; Guerrini, I. A. Uso de biossólido como substrato para produção de mudas de eucalipto. Scentia Forestalis, v.64, p.150-162, 2003.

Zhang, H.; Chen, F.; Wang, X. Evaluation of antioxidant activity of parsley essential oil and identification of antioxidant constituents. Food Research International, v.39, p.833-839, 2006. http://dx.doi. org/10.1016/j.foodres.2006.03.007 